\title{
Environmental factors influencing larval walleye pollock Theragra chalcogramma feeding in Alaskan waters
}

\author{
Steven M. Porter ${ }^{1, *}$, Lorenzo Ciannelli ${ }^{2}$, Nicola Hillgruber ${ }^{3}$, Kevin M. Bailey ${ }^{1}$, \\ Kung-Sik Chan ${ }^{4}$, Michael F. Canino ${ }^{1}$, Lew J. Haldorson ${ }^{3}$ \\ ${ }^{1}$ NOAA, Alaska Fisheries Science Center, 7600 Sand Point Way NE, Seattle, Washington 98115, USA \\ ${ }^{2}$ Centre for Ecological and Evolutionary Synthesis, University of Oslo, Department of Biology, PO Box 1050, 0316 Oslo, Norway \\ ${ }^{3}$ University of Alaska Fairbanks, Juneau Center, School of Fisheries and Ocean Sciences, 11120 Glacier Highway, Juneau, \\ Alaska 99801, USA \\ ${ }^{4}$ Department of Statistics and Actuarial Sciences, University of Iowa, Iowa City, Iowa 52242, USA
}

\begin{abstract}
This study examines potential interactions among the environmental variables likely to affect larval walleye pollock Theragra chalcogramma feeding in the sea. Walleye pollock larvae were sampled from Shelikof Strait, Gulf of Alaska, and from the eastern Bering Sea, with corresponding environmental data. Variables used in our study were time spent feeding, seawater temperature, light, prey density, wind speed and standard length of the larvae. We applied an additivity test to detect the presence of potential interactions among these variables and adopted an expansion of generalized additive models (GAMs) that allowed the inclusion of interaction terms in a non-parametric regression analysis. After testing all possible 2-way interactions among these variables, we found 4 significant terms: (1) time feeding-standard length, (2) temperature-light, (3) light-wind speed and (4) prey density-standard length. The most influential interaction term was the light-wind speed interaction, which caused a decrease of the model-generalized cross-validation (GCV, whereby lower values indicate more parsimonious models) from 0.0402 (for a model with all variables but no interaction term) to 0.0290 (for a model with all variables and this interaction), and an increase of the model explained variance by $7 \%\left(\mathrm{R}^{2}=0.89\right.$ versus 0.82$)$. This result indicates that the effect of wind speed (turbulence) on larval walleye pollock feeding is dependent upon the amount of light available. This may be due to vertical movements in the water column by both walleye pollock larvae and their prey in response to turbulence.
\end{abstract}

KEY WORDS: Larval fish feeding $\cdot$ Walleye pollock larvae $\cdot$ Generalized additive models

\section{INTRODUCTION}

The match-mismatch of feeding readiness of marine fish larvae to their prey availability in space (Lasker 1975) and time (Cushing 1975) is one of the most revered paradigms in marine ecology. However, it has become increasingly obvious that the feeding of marine fish larvae is not a simple function of prey abundance or spatial and temporal overlap (MacKenzie et al. 1990, 1994, Leggett \& Deblois 1994, Lough \&
Mountain 1996), but a complex and dynamic process with many, often interacting, factors. Insights into the effects of environmental variability on larval fish feeding-success may offer an improved understanding of larval growth and survival processes, and ultimately help elucidate the factors responsible for recruitment variability. The relationship between fish larvae and their prey is influenced by biotic and abiotic factors, including species-specific differences in sensitivity to prey, size and development of the fish larvae, prey 
density and composition, light, temperature, smallscale turbulence and water turbidity, as well as interactions between these variables (Houde 1987, Fortier et al. 1996, Lough \& Mountain 1996, Dower et al. 1998, 2002, Fiksen et al. 1998, Utne-Palm 1999, Hillgruber \& Kloppmann 2000, Kloppmann et al. 2002).

Growth and developmental rates of marine fish larvae are relatively high and result in rapid changes in swimming speed, visual acuity and digestive efficiency. These ontogenetic changes can be indirectly observed by increased feeding rates and broadened prey-size spectra, as well as enhanced vertical migration behavior. First-feeding walleye pollock Theragra chalcogramma larvae initiate exogenous feeding on copepod eggs and small naupliar stages (Canino et al. 1991, Hillgruber et al. 1995), but quickly expand their prey field to include copepodite stages and adult copepods (Nishiyama \& Hirano 1985, Kendall et al. 1987, Grover 1990). In addition, their ability to respond to physical variables, such as light and turbulence, equally increases as swimming performance improves with increasing size (Olla \& Davis 1990, Davis \& Olla 1995).

Fish larvae are visual predators that rely on sufficiently high light levels to detect prey (Paul 1983, Blaxter 1986). The threshold light level at which early walleye pollock larvae initiate prey capture is about $0.003 \mu \mathrm{mol}$ photon $\mathrm{m}^{-2} \mathrm{~s}^{-1}$ (Paul 1983). Because of this dependence on sufficient illumination, larval feeding is, in general, severely diminished at night or ceases altogether, but picks up again soon after sunrise, resulting in a diel pattern in terms of quantity and composition of prey items ingested (e.g. Last 1980, Hillgruber \& Kloppmann 2000). However, in addition to the direct effect of light on feeding incidence, changes in irradiance coupled with ontogenetic changes or turbulence can dramatically impact larval feeding rates (Fiksen et al. 1998).

Turbulence may play a major role in regulating the amount and the type of prey available to fish larvae (Dower et al. 1997). A comparison between predicted ingestion rates of fish larvae in the sea with those derived from laboratory experiments showed that feeding rate at lower prey densities was higher (near maximal ingestion) in the sea than in the laboratory (MacKenzie et al. 1990). It was suggested that smallscale turbulence could explain this discrepancy (MacKenzie et al. 1990). Small-scale turbulence introduced to the mixed layer of the water column may increase contact rates between predator and prey (Rothschild \& Osborn 1988) and thereby increase the effective prey concentration available to larval fishes. Alternatively, strong mixing events may disrupt layers of high prey density, dissipate prey concentrations and, as a consequence, lead to reduced larval feeding incidence and rates (Peterman \& Bradford 1987). To date, however, studies testing the effect of turbulence on larval feeding success have yielded complicated and often contradictory results (Landry et al. 1995, Dower et al. 1998, Hillgruber \& Kloppmann 2000). The effect of turbulence on larval fish feeding is further complicated by interacting factors such as light, larval developmental stage and size (Fiksen et al. 1998, Fiksen \& Folkvord 1999, Utne-Palm \& Stiansen 2002), and search strategy (MacKenzie \& Kiørboe 1995). In addition, the effect of turbulence should be diminished if prey density is at saturating levels (Dower et al. 2002).

The objective of the present study was to explain variability of in situ feeding of larval walleye pollock. Walleye pollock spawn in the Bering Sea and Gulf of Alaska during springtime (Kendall et al. 1996), and the larvae begin feeding about 1 wk after hatching. The range of environmental conditions that walleye pollock larvae experience is highly variable. Shelikof Strait (one of the major habitat areas for walleye pollock larvae in the Gulf of Alaska) is characterized by highly variable wind patterns, with intense storms and periods of calm during the time when walleye pollock larvae are present (Stabeno et al. 2004). Strong windmixing events during the time of first feeding have been associated with lower than expected survival of walleye pollock larvae; this may be partly the effect of turbulence on prey availability (Bailey \& Macklin 1994, Ciannelli et al. 2004).

Previous studies of larval walleye pollock feeding in Alaskan waters have shown a relationship between prey abundance and feeding success (Canino et al. 1991, Bailey et al. 1995). However, for marine fishes in general there is a lack of field studies that quantitatively address the potential interaction among the environmental covariates that affect larval fishfeeding. In the present study we applied an additivity test to detect the presence of potential interactions among the variables that can affect larval feeding. In addition, we adopted an expansion of generalized additive models (GAMs) that allows the inclusion of interaction terms in a non-parametric regression model. To our knowledge, this is the first study that explicitly addresses and models the non-additive effects of environmental variables on larval feeding. We sampled walleye pollock larvae over an extremely broad range of environmental conditions, which were selected for this study because they are easily measured and commonly utilized in recruitment analyses. Larval feeding can be examined on different scales ranging from finescale studies of larval behavior in patches of prey to large-scale comparisons of seasonal prey production and feeding success; in this study, environmental parameters were integrated over scales relevant to the daily feeding range and survival of larvae. 


\section{MATERIALS AND METHODS}

Data collection. Walleye pollock larvae were collected from 8 research cruises in Shelikof Strait, Gulf of Alaska (1989 to 1996) and from 2 cruises in the eastern Bering Sea (1992 and 1994). Altogether, 33 larval walleye pollock collections were made (Table 1). All larvae used in the analysis were collected from sunrise to approximately $6 \mathrm{~h}$ later (Table 1). Our intent was to examine the factors related to the process of gut-filling. After about 5 to $6 \mathrm{~h}$ larvae begin to egest prey, and the egestion rate depends on the rate of gut-filling (Canino \& Bailey 1995); therefore gut samples collected later in the day may not reflect feeding rates. In Shelikof Strait, samples were collected with a $60 \mathrm{~cm}$ diameter bongo sampler towed vertically from $60 \mathrm{~m}$ depth to the surface using either 333 or $505 \mu \mathrm{m}$ mesh nets (Table 1). Bering Sea collections were made with a $1 \mathrm{~m}^{2} \mathrm{MOC}$ NESS using either 335 or $505 \mu \mathrm{m}$ mesh nets, and larvae from either 70 and $90 \mathrm{~m}$ depth, or 30 and $40 \mathrm{~m}$ depth, were pooled and used in the analysis (Table 1). Although MOCNESS tows are usually conducted in vertical series, the tows available for analysis were conducted within specific depth strata in horizontal series. Thus, only MOCNESS collections within the 5 to $6 \mathrm{~h}$ after sunrise time constraint were used in our analysis, which limited us to the use of tows from the above depth strata. We assumed that there was no

Table 1. Theragra chalcogramma. Field data used to model larval feeding in Alaskan waters. Except where noted otherwise, samples were collected by $60 \mathrm{~cm}$ Bongo net with either 333 or $505 \mu \mathrm{m}$ net, towed vertically from $60 \mathrm{~m}$ to surface, in Shelikof Strait. $\mathrm{N}$ : no. of larvae examined for gut content

\begin{tabular}{|c|c|c|c|c|c|c|c|c|c|}
\hline Year & Date & $\mathrm{N}$ & $\begin{array}{c}\text { Feeding } \\
\text { period } \\
\text { (h after sunrise) }\end{array}$ & $\begin{array}{l}\text { Temp- } \\
\text { erature } \\
\left({ }^{\circ} \mathrm{C}\right)\end{array}$ & $\begin{array}{c}\text { Surface light } \\
\text { ( } \mu \text { mol photon } \\
\left.\mathrm{m}^{-2} \mathrm{~s}^{-1}\right)\end{array}$ & $\begin{array}{l}\text { Wind } \\
\text { speed } \\
\left(\mathrm{m} \mathrm{s}^{-1}\right)\end{array}$ & $\begin{array}{c}\text { Prey } \\
\text { density } \\
\left(\text { ind. } 1^{-1} \text { ) }\right.\end{array}$ & $\begin{array}{l}\text { Standard } \\
\text { length } \\
(\mathrm{mm})\end{array}$ & $\begin{array}{l}\text { Prey } \\
\text { in gut } \\
\text { (n) }\end{array}$ \\
\hline \multirow{4}{*}{1989} & \multirow[t]{2}{*}{$28 \mathrm{Apr}$} & 20 & 5.15 & 3.70 & 1006.44 & 9.27 & 7.60 & $6.12-6.97$ & 2.75 \\
\hline & & 20 & 6.27 & 3.70 & 1177.92 & 7.21 & 7.60 & $6.12-8.21$ & 1.65 \\
\hline & \multirow[t]{2}{*}{18 May } & 10 & 0.81 & 3.88 & 313.12 & 10.30 & 14.38 & $6.12-8.21$ & 1.90 \\
\hline & & 10 & 4.06 & 3.84 & 769.72 & 10.30 & 14.38 & $6.20-8.44$ & 9.70 \\
\hline 1990 & 11 May & 10 & 4.67 & 4.67 & 524.92 & 7.21 & 25.00 & $6.63-8.40$ & 6.20 \\
\hline 1991 & 4 May & 10 & 5.53 & 3.38 & 809.75 & 20.61 & 1.70 & $5.86-7.78$ & 2.20 \\
\hline 1992 & $20 \mathrm{Apr}^{\mathrm{a}, \mathrm{b}, \mathrm{c}}$ & 64 & 5.82 & 3.53 & 857.13 & 7.20 & 14.70 & $5.04-7.53$ & 0.14 \\
\hline \multirow[t]{11}{*}{1993} & \multirow[t]{4}{*}{13 May } & 20 & 0.20 & 5.30 & 0.00 & 8.24 & 24.50 & $6.17-9.03$ & 0.55 \\
\hline & & 10 & 1.98 & 5.30 & 155.14 & 9.27 & 24.50 & $6.69-9.55$ & 3.90 \\
\hline & & 10 & 2.85 & 5.30 & 243.26 & 8.24 & 24.50 & $5.39-10.59$ & 3.80 \\
\hline & & 20 & 4.52 & 5.30 & 378.53 & 8.76 & 26.50 & $5.73-8.42$ & 4.85 \\
\hline & \multirow[t]{4}{*}{30 May $^{b}$} & 20 & 0.10 & 6.04 & 0.00 & 6.18 & 22.53 & $7.47-10.24$ & 0.50 \\
\hline & & 20 & 1.38 & 6.04 & 244.85 & 6.18 & 22.53 & $7.99-11.54$ & 8.85 \\
\hline & & 20 & 3.28 & 6.19 & 650.10 & 3.09 & 28.20 & $6.86-10.41$ & 12.40 \\
\hline & & 20 & 4.10 & 6.03 & 767.17 & 4.12 & 29.20 & $7.29-10.93$ & 20.95 \\
\hline & \multirow[t]{3}{*}{31 May $^{\mathrm{b}}$} & 10 & 0.63 & 6.25 & 37.54 & 4.12 & 20.39 & $7.12-9.46$ & 9.90 \\
\hline & & 20 & 2.03 & 6.28 & 403.62 & 5.15 & 18.65 & $7.47-10.24$ & 28.55 \\
\hline & & 20 & 3.35 & 6.27 & 661.51 & 5.15 & 18.65 & $7.99-10.33$ & 34.85 \\
\hline \multirow[t]{2}{*}{1994} & $21 \mathrm{Apr}^{\mathrm{a}, \mathrm{d}}$ & 53 & 5.03 & 3.52 & 863.51 & 7.20 & 14.80 & $6.34-9.92$ & 2.89 \\
\hline & $22 \mathrm{Apr}^{\mathrm{a}, \mathrm{d}}$ & 60 & 4.70 & 3.70 & 794.22 & 3.09 & 15.40 & $6.34-9.16$ & 3.63 \\
\hline \multirow[t]{6}{*}{1995} & \multirow[t]{6}{*}{$26 \mathrm{May}^{\mathrm{b}}$} & 20 & 0.77 & 4.85 & 0.00 & 10.30 & 7.90 & $8.33-11.11$ & 0.90 \\
\hline & & 20 & 1.85 & 4.91 & 107.58 & 9.27 & 8.80 & $6.95-10.59$ & 3.10 \\
\hline & & 20 & 2.88 & 4.78 & 217.12 & 11.33 & 8.80 & $6.86-10.33$ & 3.30 \\
\hline & & 20 & 3.85 & 4.91 & 305.65 & 12.36 & 10.60 & $7.81-10.15$ & 5.65 \\
\hline & & 20 & 4.77 & 4.87 & 375.18 & 11.33 & 11.80 & $7.03-11.28$ & 10.90 \\
\hline & & 20 & 5.85 & 4.87 & 437.48 & 12.36 & 11.80 & $7.73-10.76$ & 12.20 \\
\hline \multirow[t]{7}{*}{1996} & \multirow[t]{3}{*}{4 May } & 20 & 0.00 & 4.76 & 0.00 & 15.45 & 25.50 & $5.94-10.40$ & 1.80 \\
\hline & & 20 & 2.57 & 4.84 & 436.39 & 10.30 & 26.60 & $6.63-10.09$ & 5.70 \\
\hline & & 20 & 4.83 & 4.79 & 691.90 & 9.27 & 23.10 & $6.63-9.25$ & 5.75 \\
\hline & \multirow[t]{4}{*}{8 May } & 20 & 0.00 & 4.32 & 39.11 & 7.73 & 19.20 & $7.40-10.02$ & 0.15 \\
\hline & & 20 & 1.75 & 4.28 & 312.12 & 5.15 & 20.20 & $7.32-9.63$ & 2.85 \\
\hline & & 20 & 3.70 & 4.27 & 581.58 & 5.15 & 20.60 & $6.71-9.71$ & 4.10 \\
\hline & & 20 & 5.83 & 4.36 & 863.16 & 5.15 & 16.50 & $7.40-10.09$ & 5.45 \\
\hline
\end{tabular}

${ }^{\mathrm{a}}$ MOCNESS $\left(1 \mathrm{~m}^{2}\right.$ samples from Bering Sea) ${ }^{\mathrm{b}}$ mesh size $505 \mu \mathrm{m}_{i}{ }^{\mathrm{c}} 70$ and $90 \mathrm{~m}$ depth; ${ }^{\mathrm{d}} 30$ and $40 \mathrm{~m}$ depth 
sampling bias between the 2 gear types, since walleye pollock larvae are captured equally well by bongo and Tucker tows (the latter has a towing configuration similar to that of the MOCNESS; Shima \& Bailey 1994). Immediately after retrieval of the sampling gear, the codend contents were sorted for walleye pollock larvae, which were subsequently preserved in 5 or $10 \%$ buffered formalin-seawater solution. At the laboratory, larvae were measured with an ocular micrometer to the nearest $0.08 \mathrm{~mm}$ standard length (SL) with a dissecting microscope. The midgut was dissected and the total number of prey items recorded. Preserved SL (Table 1) was adjusted for shrinkage arising from both net damage and preservation using equations described by Theilacker \& Porter (1995).

The following biological and physical environmental variables were measured at or near the time of larval collection and were used as independent variables in our study (Table 1). These were integrated over the depth range of the larval collections. Note that over the $6 \mathrm{~h}$ period of collections, a $6 \mathrm{~mm}$ larva cruising at 1 body length $\mathrm{s}^{-1}$ can swim about $130 \mathrm{~m}$, and in fact a significant portion of this displacement can be vertical over a fairly short period (Kendall et al. 1994); therefore, the depth and environmental conditions in which it captured prey during the preceeding $6 \mathrm{~h}$ are unknown.

Seawater temperature (temp): Temperature was measured using a Seabird CTD system. For samples collected using bongo tows, the mean temperature between 0 and $60 \mathrm{~m}$ depth was calculated because most feeding-stage walleye pollock larvae are encountered in this depth interval (Kendall et al. 1994). For the MOCNESS samples, mean temperature for the sampling depth interval was calculated.

Prey density (prey): Microzooplanktonic prey were sampled either with a rosette sampler equipped with 101 Niskin bottles at discrete depths or with a CalVET net vertically towed from a depth of $60 \mathrm{~m}$ to the surface. Canino et al. (1991) reported that mean prosome length of prey in the larval walleye pollock gut is approximately $200 \mu \mathrm{m}$, so microzooplankton $<350 \mu \mathrm{m}$ were used to calculate prey density (in most cases this included all copepod nauplii, copepodites and invertebrate eggs). For the larval samples collected using bongo tows, the mean prey density refers to the 0 and $60 \mathrm{~m}$ depth layer, while for the MOCNESS collections, mean prey density refers to the sampled depth interval.

Wind speed (Inws3): Wind speed was measured with a ship-based anemometer. For the formulation of the models, wind speed was cubed and used as an index of turbulence. Wind speed cubed is approximately proportional to the turbulent dissipation rate $\varepsilon$ (Oakey \& Elliot 1982). The natural log data-transformation was applied to these data.
Light anomaly (light): Photosynthetically active radiation at the sea surface at the time of larval sampling was estimated from a numerical model based on atmospheric conditions, date, time of day, and latitude and longitude (Gregg \& Carder 1990). The estimated irradiance values were pooled and regressed against $h$ after sunrise (the time when the larvae were collected), and the residuals were used as the values of light in the GAM analysis. This helped to avoid multicollinearity with time feeding, which was used as another independent variable in the GAM (see next subsection). The newly calculated light values indicated whether the light level at the sea surface at the time of sampling was higher or lower for that time of day based on all the data.

Time feeding (feed.time): This was defined as the number of hours from sunrise to the time of larval collection (Table 1), and was also included as an independent variable. This definition is reasonable since walleye pollock larvae are visual predators that cease feeding during the night (Paul 1983, Canino \& Bailey 1995).

From each collection, 10 to 64 larvae were examined and the mean number of prey in the gut (NPG) and the mean SL (used as an independent variable) were used as the value for each collection to avoid pseudoreplication. Normal probability plots indicated that the dependent variable NPG (Table 1) was not normally distributed, so the fourth root data-transformation was used.

Data analysis. We used non-parametric regression models (i.e. GAMs) to isolate the factors affecting larval feeding (NPG) in the field: 2 different model formulations were adopted, an additive and a non-additive formulation. Prior to analysis, the data were weighted by the number of larvae examined from each station. For the additive GAM formulation, our model selection criterion was based on a step-wise approach, aimed at removing covariates with a p-value $>0.05$ and minimizing the model-generalized cross-validation (GCV; Wood 2000). The GCV is a measure of the predictive error of the model and thus takes into account not only the fit, but also the model complexity (i.e. degrees of freedom). We initially included all the covariates (without interaction terms) in the GAM model of feeding by larval walleye pollock. We then eliminated, one by one, all the covariates whose partial effect had the lowest significance level (i.e. the covariate with a p-value typically $>0.05$ was removed). This process was repeated until the model GCV was minimized, which also coincided with all covariates having a p-value $\leq 0.05$.

We applied the additivity test developed by Chan et al. (2003) to detect the presence of potential interactions between the covariates retained in the final additive GAM formulation. The additivity test was limited to second-order terms (i.e. 2-way interactions). The re- 
jection level (i.e. significant interaction) was set at a $p$-value $\leq 0.05$. Significant second-order interaction terms were included in the non-additive GAM formulation, and the validity of the model was re-assessed adopting the step-wise procedure previously described for the additive GAM formulation. To avoid problems with model over-parameterization we never included more than 1 interaction term in a single nonadditive model formulation. Thus, the non-additive terms, as detected from the additivity test, were assessed in multiple GAM models. The inclusion of the interaction term in a GAM formulation adopted the multiplicative approach described by Hastie \& Tibshirani (1990) and applied by Ciannelli et al. (2004). Specifically, the interaction term was formed by the product between the 2 standardized and shifted interacting covariates. Covariates were shifted (i.e. a constant added to their standardized series) so that their value was $\geq 0$, and consequently their product was a monotonic increasing function.

\section{RESULTS}

\section{Additive GAM}

All the inspected independent variables were retained in the final additive model formulation of larval feeding; the GCV score was 0.0402, and $82 \%$ of the variance was explained. Each variable had a positive effect on NPG, although some effects were nonlinear (Fig. 1). NPG increased from sunrise to approximately $4 \mathrm{~h}$ after sunrise and remained at a nearly constant level thereafter, presumably due to the onset of digestive processes (Canino \& Bailey 1995). Temperature had a strong, positive, linear effect on feeding. The effects of both light anomaly and wind speed were nonlinear and most pronounced at the highest values of each factor. For integrated prey density, NPG increased up to maximum level at approximately 18 prey $\mathrm{l}^{-1}$. For larvae between 6 and $\sim 8.5 \mathrm{~mm}$ in length, NPG increased with increasing larval size. Thus,
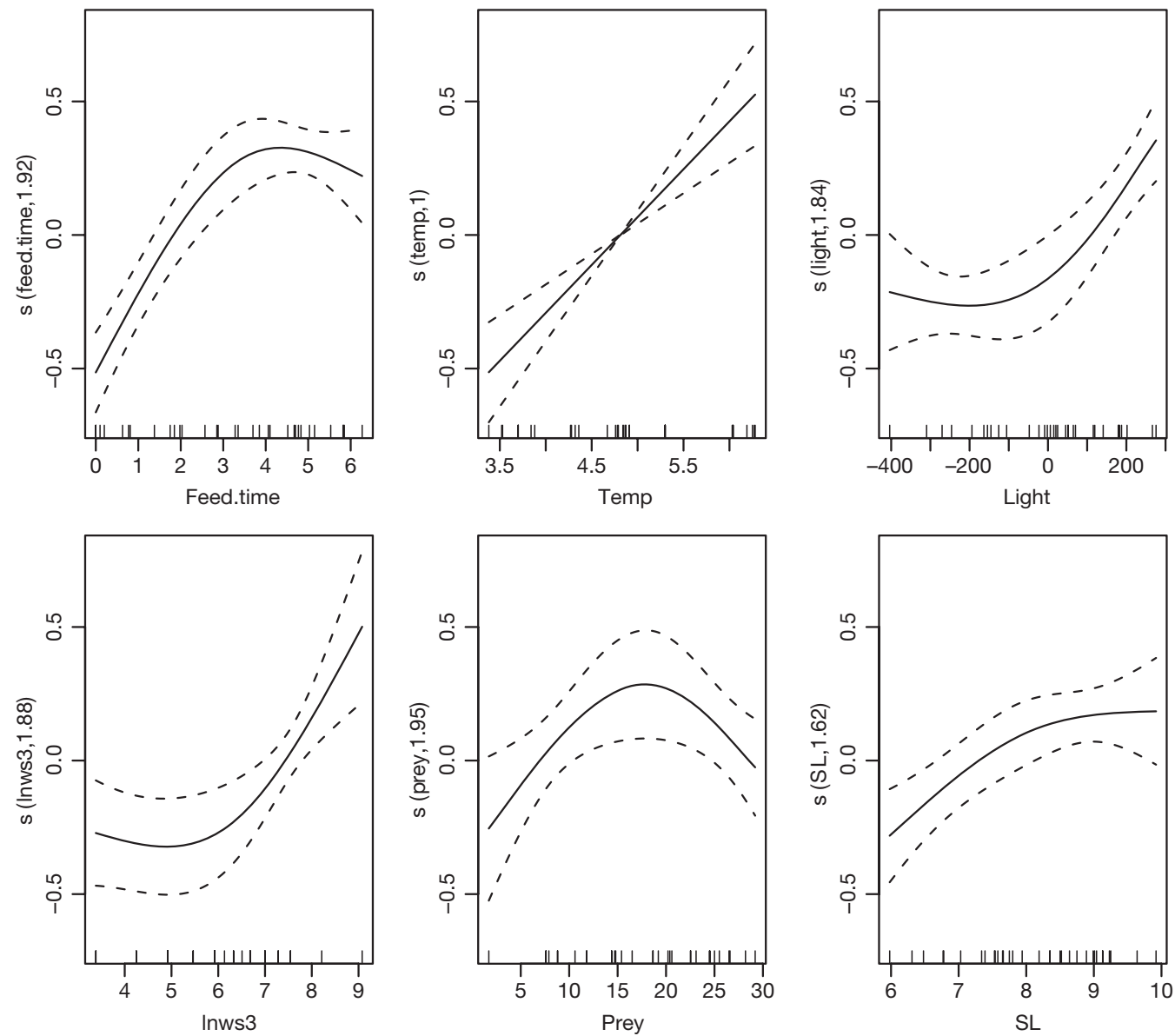

Fig. 1. Theragra chalcogramma. Partial additive effect on larval feeding of each environmental variable included in generalized additive model. Predicted result (no. of prey in gut, NPG) at specified level of an environmental variable is given by sum of partial effects of each variable plus a model constant. Dashed lines: \pm 2 SE of mean estimated effect (continuous line). Whiskers on $x$-axis: locations of measurements for that covariate. $\mathrm{s}(y$-axis): estimated degrees of freedom for each partial effect, where $<0$ indicate that variable has negative effect on NPG and values $>0$ indicate positive effect. SL: standard length; lnw3: wind speed 
according to our additive model, walleye pollock larvae initiate feeding after sunrise and need approximately $4 \mathrm{~h}$ to fill their guts. Best feeding conditions occur when light levels and wind speeds are high, and the integrated prey density is near $18 \mathrm{l}^{-1}$. The results also showed that larvae rapidly improve their feeding ability between 6 and $8.5 \mathrm{~mm} \mathrm{SL}$, possibly due to rapid development of swimming and feeding structures during early fish ontogeny (i.e. Hunt von Herbing et al. 2001). The GCV of a model with no independent variables (i.e. NPG was modeled by a constant) was 0.2106, which is higher than the 0.0402 for the final additive model, indicating that the observed effects are likely to be real.

Because of concern that different samples obtained by bongo and MOCNESS tows could influence the results, we also ran the model without the MOCNESS data. The only difference in the results was that length (SL) dropped out as a significant factor. This appears to be the result of the inclusion of a smaller size range of larvae in the MOCNESS samples. Since all environmental factors remained significant, we opted to include the MOCNESS data in further model-testing to increase sample size and to include the broader length range of larvae.

\section{Additivity test}

After testing all possible 2-way interactions between the variables included in the additive GAM, it was determined that 4 of the 2 -way interactions were significant at the 0.05 rejection level (Table 2). The significant interactions were time feeding-SL, temperature-

Table 2. Theragra chalcogramma. Results of additivity test (Chan et al. 2003) used to determine significant 2-way interactions between all independent variables used in generalized additive model, GAM. ${ }^{*},{ }^{* *}$ Significant at $\mathrm{p}=0.05$ and $\mathrm{p}=0.01$ level, respectively

\begin{tabular}{|lc|}
\hline Independent variables tested & p-value \\
\hline Time feeding, temperature & 0.19 \\
Time feeding, light anomaly & 0.61 \\
Time feeding, prey density & 0.10 \\
Time feeding, standard length & $0.03^{*}$ \\
Time feeding, wind speed & 0.46 \\
Temperature, light anomaly & $0.002^{* *}$ \\
Temperature, prey density & 0.09 \\
Temperature, standard length & 0.98 \\
Temperature, wind speed & 0.24 \\
Light anomaly, prey density & 0.24 \\
Light anomaly, standard length & 0.37 \\
Light anomaly, wind speed & $0.03^{*}$ \\
Prey density, standard length & $0.03^{*}$ \\
Prey density, wind speed & 0.06 \\
Standard length, wind speed & 0.09 \\
\hline
\end{tabular}

light anomaly, light anomaly-wind speed, and prey density-SL.

\section{Inclusion of an interaction term in additive GAM}

There was no improvement in the additive GAM with the inclusion of the temperature-light anomaly interaction $(p$-value $=0.30$, model GCV $=0.0427)$; thus its effect on larval feeding was not further explored. The inclusion of time feeding-SL or prey density-SL as an interaction term resulted in further improvement of the model GCV (Table 3, Models A,B). The single variable SL became non-significant in both of these non-additive models and was removed. All other additive variables had similar effects to those already described for the additive model formulation (Fig. 1). The effect of the interaction terms was explored with 3D graphs, in which the non-additive models were used to predict NPG. The 2 interacting covariates were varied throughout their entire range, while all other non-interacting covariates were kept constant at their mean value. From these 3D plots, we interpreted the time feeding-SL and prey density-SL interactions as ontogenetic changes in feeding ability (Fig. 2). As prey density and time spent feeding increase, larger larvae are

Table 3. Theragra chalcogramma. GAM analysis of larval feeding, with 1 interaction term added. Model A: NPG (no. of prey in gut $)=$ constant + time feeding + temp + light + lnws 3 (wind speed) + prey + feeding time $\times$ SL (standard length); GCV (generalized cross-validation) score $=0.0347, \mathrm{R}^{2}=0.84$. Model $\mathrm{B}$ : $\mathrm{NPG}=$ constant + time feeding + temp + light $+\operatorname{lnws} 3+$ prey + prey $\times$ SL; GCV score $=0.0397, \mathrm{R}^{2}=0.82$. Model $\mathrm{C}: \mathrm{NPG}=$ constant + time feeding + temp + light + lnws $3+$ prey + SL + light $x$ lnws3; GCV score $=0.0290, \mathrm{R}^{2}=0.89$

\begin{tabular}{|llcc|}
\hline \multirow{2}{*}{ Model } & Variable & Estimated df & $\mathrm{p}$ \\
\hline A & Time feeding & 1.61 & 0.01 \\
& Temperature & 1.00 & $3.69 \times 10^{-11}$ \\
& Light & 2.00 & $2.43 \times 10^{-6}$ \\
& lnws3 & 1.91 & 0.002 \\
& Prey & 1.99 & 0.02 \\
& Time feeding $\times$ SL & 1.67 & $1.23 \times 10^{-5}$ \\
B Time feeding & 1.93 & $8.17 \times 10^{-13}$ \\
& Temperature & 1.00 & $1.34 \times 10^{-7}$ \\
& Light & 2.00 & $3.40 \times 10^{-5}$ \\
& lnws3 & 1.93 & 0.003 \\
& Prey & 1.79 & 0.01 \\
Prey $\times$ SL & 1.78 & 0.001 \\
Time feeding & 1.97 & $<2.22 \times 10^{-16}$ \\
& Temperature & 1.31 & $1.30 \times 10^{-9}$ \\
& Light & 2.00 & $1.26 \times 10^{-5}$ \\
lnws3 & 1.99 & $2.12 \times 10^{-7}$ \\
& Prey & 1.97 & 0.0001 \\
& SL & 1.08 & $6.60 \times 10^{-6}$ \\
Light $\times$ lnws3 & 1.02 & 0.0004 \\
\hline
\end{tabular}


A

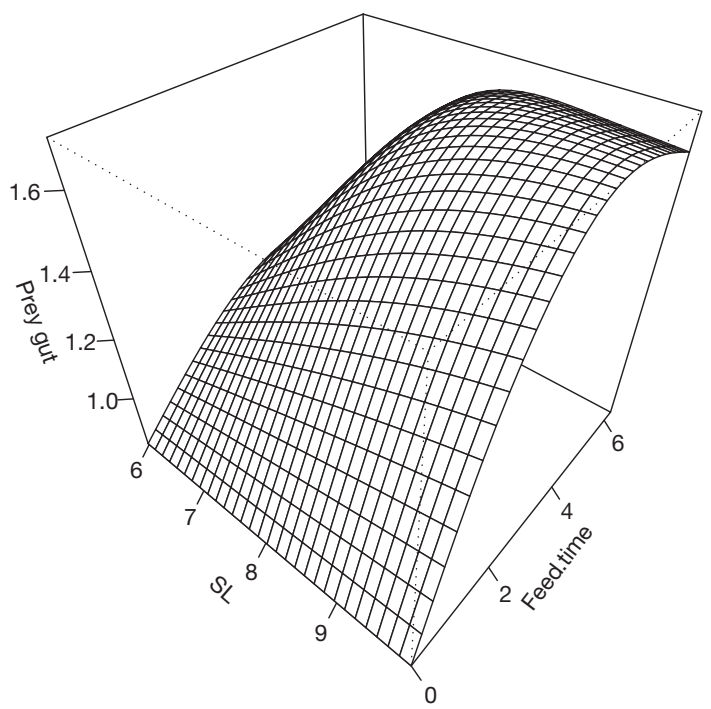

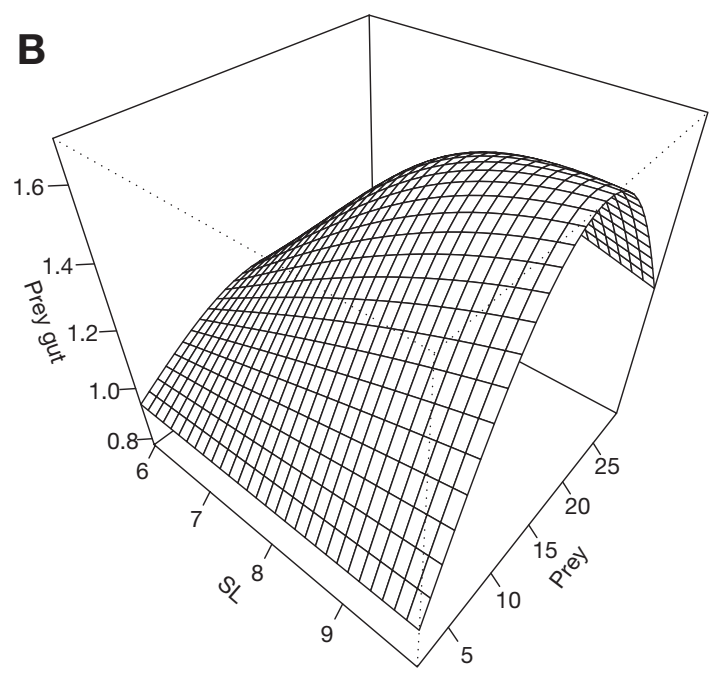

Fig. 2. Theragra chalcogramma. Predicted larval feeding (NPG) as a function of interacting covariates. In model predictions, interacting covariates span their entire range, while all other covariates (not shown) retain their mean value; prey gut $=$ predicted NPG. (A) Standard length and time spent feeding interaction (Table 3, Model A); (B) standard length and prey-density interaction (Table 3, Model B)
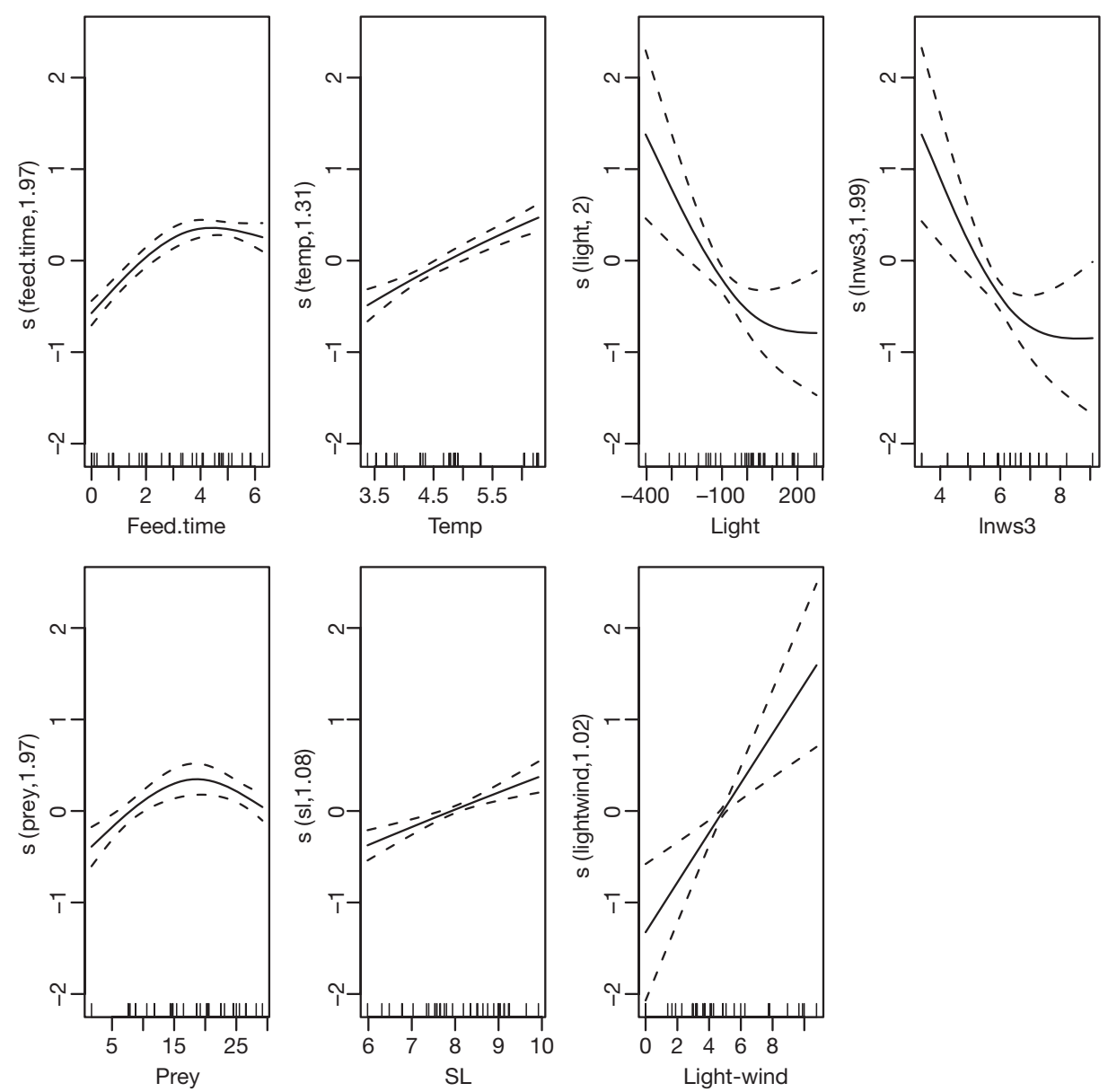

Fig. 3. Theragra chalcogramma. Partial additive effect on larval feeding for model that includes light and wind-speed interaction (Table 3, Model C). Further details as in Fig. 1 able to consume more prey than smaller ones.

The inclusion of the light anomaly-wind speed interaction term in the additive formulation resulted in a further improvement of the model (Table 3, Model C). All the additive variables also contributed toward a reduction of the model GCV. Most of the non-interacting covariates had similar positive effects on NPG as the additive formulation (Fig. 3). However, the additive effect of light anomaly and wind speed became negative (Fig. 3). This change in the effect of light and wind speed from positive to negative, when comparing the additive to the nonadditive model formulations, is probably due to their strong interacting effect. In fact, the 3D plot showed that the effect of turbulence on feeding cannot be assessed in isolation but is dependent upon the amount of light (Fig. 4). At higher light levels, feeding improves as wind speed increases. At lower light levels, feeding conditions degrade as wind increases. 


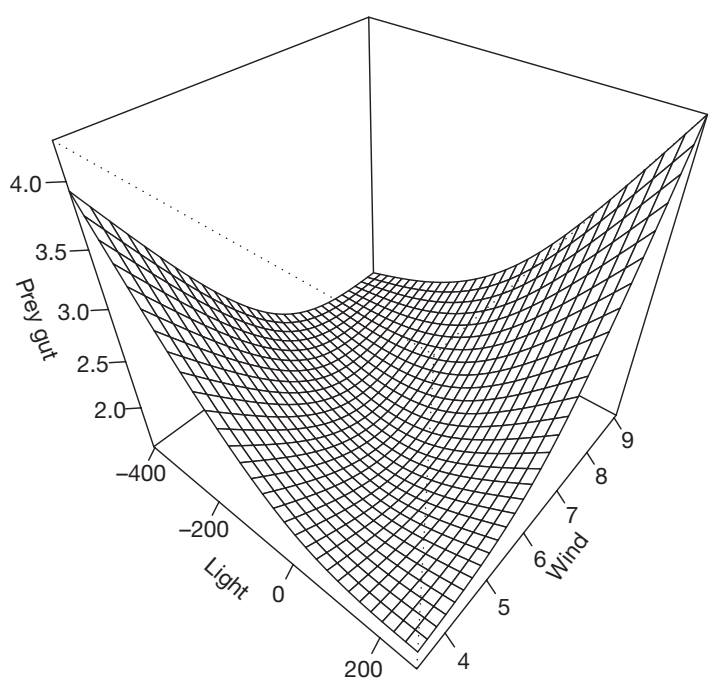

Fig. 4. Theragra chalcogramma. Predicted larval feeding (NPG) as a function of interaction between light and wind speed (Table 3, Model C). In model predictions, interacting covariates span their entire range, while all other covariates (not shown) retain their mean value; prey gut: predicted NPG

Among the 3 inspected models with interaction terms, the most parsimonious (i.e. best fit with least number of parameters) was the one that included the light-wind speed interaction. Compared to the additive model, the non-additive model with this interaction decreased the model GCV from 0.0402 to 0.0290 , and increased the model explained variance by $7 \%\left(R^{2}=0.89\right.$ versus 0.82), making it the best overall model.

\section{DISCUSSION}

Our results indicate that feeding in walleye pollock larvae is a complex process depending not only on individual physical and biological factors, but on the interaction of these factors as well. Our best model explained a substantial portion of the variance (89\%) and included an interaction between light and wind speed. This interaction had a greater effect on larval walleye pollock numerical feeding intensity than prey density over the range of values sampled. Our model showed increasing prey in the gut up to about $4 \mathrm{~h}$ after sunrise. This result corresponds well with the 4 to $5 \mathrm{~h}$ described for field collected walleye pollock (Canino \& Bailey 1995). Optimal prey density for feeding was predicted to be between 15 and $20 \mathrm{l}^{-1}$, which is slightly lower than the proposed prey densities $\left(>20\right.$ prey $\mathrm{l}^{-1}$ ) required for walleye pollock larvae in Shelikof Strait, Gulf of Alaska, to be in healthy condition (Theilacker et al. 1996). The model also predicted increased numerical feeding intensity with increasing larval size, indicating that the predatory performance of larval walleye pollock might improve with progressing ontogeny. This is in agreement with other studies that have shown that shortly after hatching fish larvae dramatically improve their functional morphology, physiology and subsequent behavioral patterns resulting in advanced swimming performance and foraging success (Osse 1990, Porter \& Theilacker 1999, Hunt von Herbing \& Gallager 2000, Hunt von Herbing 2001). Similarly, increases in feeding were predicted under conditions of rising temperature, which has been shown to boost feeding rates in other studies on marine fish larvae (Houde 1989, Meekan et al. 2003). The observed positive effect of temperature on feeding success might be the result of temperature affecting not only the larval physiology and therefore swimming performance but also the physics of the surrounding environment by decreasing its viscosity (Hunt von Herbing 2002).

Wind-induced small-scale turbulence increases the contact rate between predator and prey and can thus increase larval ingestion rates. This relationship has been hypothesized to be dome-shaped rather than linear (MacKenzie et al. 1994); according to this model, maximum feeding rates occur at intermediate levels of turbulence, while highly turbulent conditions will reduce the rate of successful larval prey capture, which will lead to an overall decrease in ingestion rates. Our model predicted higher feeding rates under high turbulence levels; it did not show a decrease over the range of values observed (the maximum wind speed measured in our study was approximately $20 \mathrm{~m} \mathrm{~s}^{-1}$ (a speed estimated to reduce ingestion in Atlantic cod Gadus morhua larvae; MacKenzie et al. 1994), possibly because walleye pollock larvae avoid high turbulence situations by moving deeper down the water column (Olla \& Davis 1990, Kendall et al. 1994). However, marine fish larvae are visual predators, and must rely on sufficient illumination to detect and successfully ingest prey (Paul 1983, Blaxter 1986). Thus, larval ingestion rates should be a function of not only turbulence but also light intensity, possibly with interacting effects. In a modeling study on larval Atlantic herring Clupea harengus and Atlantic cod G. morhua, both turbulence and light had a strong effect on larval ingestion rates (Fiksen et al. 1998). This is in agreement with our results, where under high-light conditions feeding improved as wind speed increased. Laboratory studies have also shown an interaction between light levels and turbulence for feeding of larval herring C. harengus (Utne-Palm \& Stiansen 2002).

In the present study, the factors having the most influence on larval walleye pollock feeding success were light and wind speed (turbulence), with the amount of light mediating the effect of turbulence on feeding. Since turbulence may cause both fish larvae (Olla \& Davis 1990, Kendall et al. 1994, Lough \& Mountain 
1996) and the developmental stages of copepods (Lagadeuc et al. 1997, Incze et al. 2001) to dwell deeper in the water column, one effect of turbulence may be the concentration of both predators and prey in deeper waters. This has been hypothesized by Franks (2001) in a modeling study that concluded that turbulenceavoidance behavior can lead to significant increases in predator-prey concentrations below the mixed layer. Similar avoidance behavior was reported for other marine fish larvae; namely, in Atlantic herring Clupea harengus larvae, high wind velocities caused a dispersion of the larval population and an increase in mean depth distribution (Heath et al. 1988). The distribution of blue whiting Micromesistius poutassou larvae also appeared to be deeper during high-wind than during low-wind conditions (Hillgruber \& Kloppmann 2000). Organisms that would most benefit from this turbulence avoidance behavior are older larvae and zooplanktonic prey that swim sufficiently fast to be capable of leaving the mixed layer quickly after the onset of wind-mixing. Since pollock larvae are visual predators, they may need more surface downwelling light to successfully feed deeper in the water column. Therefore, increased turbulence will be most beneficial for walleye pollock larvae at high surface-light levels. When turbulence increases and light levels are low, feeding success of larvae at depth will decrease accordingly. In a modeling study, Heath (1989) found that a similar interaction between high turbulence and low light reduced feeding in larval herring C. harengus. Alternatively, switching to a different-sized prey or a different prey type may be a strategy to feed at low light and high turbulence. For example, radiated shanny Ulvaria subbifurcata larvae tended to ingest fewer, but larger, prey items under turbulent conditions (Dower et al. 1998). However, since our data only provide numerical feeding intensity, we lack the resolution necessary to identify any prey-shift behavior in walleye pollock larvae. As a data exploration technique, the GAM results suggest interesting ramifications of potential turbulence-avoidance behavior of walleye pollock larvae, warranting finer-scale sampling studies.

Our results also indicate that larval feeding decreases in the presence of high light and low wind. This may be a consequence of a lack of spatial overlap between larval walleye pollock and their prey during these conditions. Walleye pollock larvae avoid light levels above $13 \mu \mathrm{mol}$ photon $\mathrm{m}^{-2} \mathrm{~s}^{-1}$ by moving deeper into the water column (Olla \& Davis 1990). Thus, under conditions of high light and low turbulence, walleye pollock larvae might move deeper, resulting in reduced feeding if their copepod prey remain at shallower depths. Alternatively, feeding could simply be reduced at high light intensities, as has been shown for larval Atlantic cod Gadus morhua (Huse 1994).
There were some assumptions and sources of variability that could not be controlled in the present study. In simulated net-capture experiments there was no significant loss of gut contents of walleye pollock larvae (Canino \& Bailey 1995), so it was assumed for the present study that loss of gut contents during collection was negligible. The period of time that the larvae experienced the environmental conditions in which they were collected could not be determined, but conditions probably do not radically change over the $6 \mathrm{~h}$ period of accumulation of prey in their gut. Also, wind speed was used as a measure of turbulence. Dower et al. (1998) have cautioned about using wind speed in this manner due to the complexity of turbulent regimes in coastal areas, i.e. there are factors in addition to wind speed that can affect turbulence in the water column. Furthermore, turbulent energy-dissipation rates calculated from wind speeds may not equal the values measured in situ (Reiss et al. 2002). In general though, where complex mixing conditions are not known to occur, wind-based models explain a high proportion of the variability in surface-layer turbulent dissipation rates (MacKenzie \& Leggett 1993). In our study, we sampled in relatively deep water (bottom depth $>100 \mathrm{~m}$ ) and were mainly interested in the impact of passing storms on larval feeding; under these conditions, wind speed seems to comprise a reasonable proxy for turbulence, although we recognize that other factors may influence the level of turbulence at depth. We also assumed an even distribution of walleye pollock larvae and prey throughout the upper $60 \mathrm{~m}$ of the water column, even though ichthyoplankton and zooplankton distributions are typically vertically structured (e.g. Folt \& Burns 1999, Napp et al. 2000). In addition to numerical feeding intensity used as a measure of larval feeding success, turbulence can also modify larval feeding behavior at other levels, such as alteration of swimming behavior, or changes in prey size or preytaxa composition. However, our diet data did not provide the resolution necessary to determine these changes in feeding behavior. How turbulence affects prey also should be considered. For example, the copepod Acartia clausi is more active under turbulent conditions (Saiz \& Alcaraz 1992), which could make them more vulnerable to predation. Finally, irradiance in our study was not measured, but was estimated from a model $_{i}$ it is recognized that there are many factors that can influence the transmission of light through the water column and also larval feeding (e.g. water clarity). Our intent was to examine common and easily measured environmental factors often used in recruitment analyses to determine which may be important to larval feeding success.

Larval feeding in relation to environmental conditions can be studied on different scales. We encourage 
fine-scale sampling of larvae and environmental conditions, and believe that other important factors will emerge under closer observation. However, swimming may displace larvae from the environment in which they fed, uncoupling the gut contents at the time of capture from environmental conditions under which feeding occurred. Kendall et al. (1994) demonstrated that the mean depth of larvae can change by up to $30 \mathrm{~m}$ during relatively short time periods during daylight intervals. We integrated sampling over the potential depth range of feeding walleye pollock larvae, as it is uncertain where in the water column larvae had actually captured prey in the previous $6 \mathrm{~h}$.

Despite the listed sources of variability and the vertical integration of our samples, our model explained $89 \%$ of the observed variance in feeding, a result enabled by the wide range of the environmental conditions sampled. The results of the fitted models conform to theoretical expectations from known parameters influencing larval feeding, and provides new information on the interacting role of environmental variables. We demonstrate that for walleye pollock larvae, feeding success cannot be inferred from prey density alone. Additionally, the exploratory models presented here clarify the role of turbulence and its interdependence with light intensity on larval feeding, and lead to new hypotheses on the role of light and turbulence that can be field-tested.

Acknowledgements. We thank R. Davis for irradiance calculations, J. Napp for providing microzooplankton data and comments, and for patience in the lengthy development of this project, and numerous FOCI scientists who aided in the collection of data. This research is contribution FOCI-0541 to NOAA's Fisheries-Oceanography Coordinated Investigations.

\section{LITERATURE CITED}

Bailey KM, Macklin SA (1994) Analysis of patterns in larval walleye pollock Theragra chalcogramma survival and wind mixing events in Shelikof Strait, Gulf of Alaska. Mar Ecol Prog Ser 113:1-12

Bailey KM, Canino MF, Napp JM, Spring SM, Brown AL (1995) Contrasting years of prey levels, feeding conditions and mortality of larval walleye pollock Theragra chalcogramma in the western Gulf of Alaska. Mar Ecol Prog Ser 119:11-23

Blaxter JHS (1986) Development of sense organs and behaviour of teleost larvae with special reference to feeding and predator avoidance. Trans Am Fish Soc 115:98-114

Canino MF, Bailey KM (1995) Gut evacuation of walleye pollock larvae in response to feeding conditions. J Fish Biol 46:389-403

Canino MF, Bailey KM, Incze LS (1991) Temporal and geographic differences in feeding and nutritional condition of walleye pollock larvae Theragra chalcogramma in Shelikof Strait, Gulf of Alaska. Mar Ecol Prog Ser 79:27-35

Chan KS, Kristoffersen AB, Stenseth NC (2003) Bürmann expansion and test for additivity. Biometrika 90:209-222

Ciannelli L, Chan KS, Bailey KM, Stenseth NC (2004) Non- additive effects of the environment in the survival of a large marine fish population. Ecology 85:3418-3427

Cushing DH (1975) Marine ecology and fisheries. Cambridge University Press, Cambridge

Davis MW, Olla BL (1995) Formation and maintenance of aggregations in walleye pollock, Theragra chalcogramma, larvae under laboratory conditions: role of visual and chemical stimuli. Environ Biol Fish 44:385-392

Dower JF, Miller TJ, Leggett WC (1997) The role of microscale turbulence in the feeding ecology of larval fish. Adv Mar Biol 31:170-220

Dower JF, Pepin P, Leggett WC (1998) Enhanced gut fullness and an apparent shift in the size selectivity by radiated shanny (Ulvaria subbifurcata) larvae in response to increased turbulence. Can J Fish Aquat Sci 55:128-142

Dower JF, Pepin P, Leggett WC (2002) Using patch studies to link mesoscale patterns of feeding and growth in larval fish to environmental variability. Fish Oceanogr 11: $219-232$

Fiksen Ø, Folkvord A (1999) Modelling growth and ingestion processes in herring Clupea harengus larvae. Mar Ecol Prog Ser 184:273-289

Fiksen Ø, Utne ACW, Aksnes DL, Eiane K, Helvik JV, Sunby S (1998) Modelling the influence of light, turbulence, and ontogeny on ingestion rates in larval cod and herring. Fish Oceanogr 7:355-363

Folt CL, Burns CW (1999) Biological drivers of zooplankton patchiness. Trends Ecol Evol 14:300-305

Fortier L, Gilbert M, Ponton D, Ingram RG, Robineau B, Legendre L (1996) Impact of freshwater on a subarctic coastal ecosystem under seasonal sea ice (southeastern Hudson Bay, Canada). III. Feeding success of marine fish larvae. J Mar Syst 7:251-265

Franks PJS (2001) Turbulence avoidance: an alternative of turbulence-enhanced ingestion rates in the field. Limnol Oceanogr 46:959-963

Gregg WW, Carder KL (1990) A simple spectral solar irradiance model for cloudless maritime atmospheres. Limnol Oceanogr 35:1657-1675

Grover JJ (1990) Feeding ecology of late-larval and early juvenile walleye pollock Theragra chalcogramma from the Gulf of Alaska in 1987. Fish Bull US 88:463-470

Hastie TJ, Tibshirani RJ (1990) Generalized additive models. Chapman \& Hall, London

Heath M (1989) A modelling and field study of grazing by herring larvae. Rapp P-V Réun Cons Int Explor Mer 191: 233-247

Heath M, Henderson EW, Baird DL (1988) Vertical distribution of herring larvae in relation to physical mixing and illumination. Mar Ecol Prog Ser 47:211-228

Hillgruber N, Kloppmann M (2000) Vertical distribution and feeding of larval blue whiting in turbulent waters above Porcupine Bank. J Fish Biol 57:1290-1311

Hillgruber N, Haldorson LJ, Paul AJ (1995) Feeding selectivity of larval walleye pollock Theragra chalcogramma in the oceanic domain of the Bering Sea. Mar Ecol Prog Ser 120:1-10

Houde ED (1987) Fish early life dynamics and recruitment variability. Am Fish Soc Symp 2:17-29

Houde ED (1989) Comparative growth, mortality, and energetics of marine fish larvae: temperature and implied latitudinal effects. Fish Bull US 87:471-495

Hunt von Herbing I (2001) Development of feeding structures in larval fish with different life histories: winter flounder and Atlantic cod. J Fish Biol 59:767-782

Hunt von Herbing I (2002) Effects of temperature on larval fish swimming performance: the importance of physics to 
physiology. J Fish Biol 61:865-876

Hunt von Herbing I, Gallager SM (2000) Foraging behavior in early Atlantic cod larvae (Gadus morhua) feeding on a protozoan (Balanion sp.) and a copepod nauplius (Pseudodiaptomus sp.). Mar Biol 136:591-602

Hunt von Herbing I, Gallager SM, Halteman W (2001) Metabolic costs of pursuit and attack in early larval Atlantic cod. Mar Ecol Prog Ser 216:201-212

Huse I (1994) Feeding at different illumination levels in larvae of three marine teleost species: cod, Gadus morhua L., plaice, Pleuronectes platessa L., and turbot, Scophthalmus maximus (L.). Aquacult Fish Manag 25:687-695

Incze LS, Hebert D, Wolff N, Oakey N, Dye D (2001) Changes in copepod distributions associated with increased turbulence from wind stress. Mar Ecol Prog Ser 213:229-240

Kendall AW Jr, Clarke ME, Yoklavich MM, Boehlert GW (1987) Distribution, feeding, and growth of larval walleye pollock, Theragra chalcogramma, from Shelikof Strait, Gulf of Alaska. Fish Bull US 85:499-521

Kendall AW Jr, Incze LS, Ortner PB, Cummings SR, Brown PK (1994) The vertical distribution of eggs and larvae of walleye pollock, Theragra chalcogramma, in Shelikof Strait, Gulf of Alaska. Fish Bull US 92:540-554

Kendall AW Jr, Schumacher JD, Kim S (1996) Walleye pollock recruitment in Shelikof Strait: applied fisheries oceanography. Fish Oceanogr 5:4-18

Kloppmann MHF, Hillgruber N, von Westernhagen H (2002) Wind-mixing effects on feeding success and condition of blue whiting larvae in the Porcupine Bank area. Mar Ecol Prog Ser 235:263-277

Lagadeuc Y, Boulé M, Dodson JJ (1997) Effect of vertical mixing on the vertical distribution of copepods in coastal waters. J Plankton Res 19:1183-1204

Landry F, Miller TJ, Leggett WC (1995) The effects of smallscale turbulence on the ingestion rate of fathead minnow (Pimephales promelas) larvae. Can J Fish Aquat Sci 52: 1714-1719

Lasker R (1975) Field criteria for survival of anchovy larvae: the relation between inshore chlorophyll maximum layers and successful first feeding. Fish Bull US 73:453-462

Last JM (1980) The food of twenty species of fish larvae in the west-central North Sea. Fish Res Tech Rep Minst Agric Fish Food Lowestoft 60:1-44

Leggett WC, Deblois E (1994) Recruitment in marine fishes: is it regulated by starvation and predation in the egg and larval stages? Neth J Sea Res 32:119-134

Lough RG, Mountain DG (1996) Effect of small-scale turbulence on feeding rates of larval cod and haddock in stratified waters on Georges Bank. Deep-Sea Res II 43:1745-1772

MacKenzie BR, Kiørboe T (1995) Encounter rates and swimming behavior of pause-travel and cruise larval fish predators in calm and turbulent laboratory environments. Limnol Oceanogr 40:1278-1289

MacKenzie BR, Leggett WC (1993) Wind-based models for estimating the dissipation rates of turbulent energy in aquatic environments: empirical comparisons. Mar Ecol Prog Ser 94:207-216

MacKenzie BR, Leggett WC, Peters RH (1990) Estimating larval fish ingestion rates: can laboratory derived values be reliably extrapolated to the wild? Mar Ecol Prog Ser 67: 209-225

MacKenzie BR, Miller TJ, Cyr S, Leggett WC (1994) Evidence for a dome-shaped relationship between turbulence and

Editorial responsibility: Otto Kinne (Editor-in-Chief), Oldendorf/Luhe, Germany larval fish ingestion rates. Limnol Oceanogr 39:1790-1799

Meekan MG, Carleton JH, McKinnon AD, Flynn K, Furnas M (2003) What determines the growth of tropical reef fish larvae in the plankton: food or temperature? Mar Ecol Prog Ser 256:193-204

Napp JM, Kendall AW, Schumacher JD (2000) A synthesis of biological and physical processes affecting the feeding environment of larval walleye pollock (Theragra chalcogramma) in the eastern Bering Sea. Fish Oceanogr 9: 147-162

Nishiyama T, Hirano K (1985) Prey size and weight relations in larval walleye pollock (Theragra chalcogramma). Bull Plankton Soc Jpn 32:45-59

Oakey NS, Elliot JA (1982) Dissipation within the surface mixed layer. J Phys Oceanogr 12:171-185

Olla BL, Davis MW (1990) Effects of physical factors on the vertical distribution of larval walleye pollock Theragra chalcogramma under controlled laboratory conditions. Mar Ecol Prog Ser 63:105-122

Osse JWM (1990) Form changes in fish larvae in relation to changing demands of function. Neth J Zool 40:362-385

Paul AJ (1983) Light, temperature, nauplii concentrations, and prey capture by first feeding pollock larvae Theragra chalograma. Mar Ecol Prog Ser 13:175-179

Peterman RM, Bradford MJ (1987) Wind speed and mortality rate of a marine fish, the northern anchovy (Engraulis mordax). Science 235:354-355

Porter SM, Theilacker GH (1999) The development of the digestive tract and eye in larval walleye pollock, Theragra chalcogramma. Fish Bull US 97:722-729

Reiss C, Anis A, Taggart CT, Dower J, Ruddick B (2002) Relationships among vertically structured in situ measures of turbulence, larval fish abundance and feeding success and copepods on Western Bank, Scotian Shelf. Fish Oceanogr 11:156-174

Rothschild BJ, Osborn TR (1988) Small-scale turbulence and plankton contact rates. J Plankton Res 10:465-474

Saiz E, Alcaraz M (1992) Free-swimming behaviour of Acartia clausi (Copepoda: Calanoida) under turbulent water movement. Mar Ecol Prog Ser 80:229-236

Shima M, Bailey KM (1994) Comparative analysis of ichthyoplankton sampling gear for early life stages of walleye pollock (Theragra chalcogramma). Fish Oceanogr 3:50-59

Stabeno PJ, Bond NA, Hermann AJ, Kachel NB, Mordy CW, Overland JE (2004) Meteorology and oceanography of the northern Gulf of Alaska. Cont Shelf Res 24:859-897

Theilacker GH, Porter SM (1995) Condition of larval walleye pollock, Theragra chalcogramma, in the western Gulf of Alaska assessed with histological and shrinkage indices. Fish Bull US 93:333-344

Theilacker GH, Bailey KM, Canino MF, Porter SM (1996) Variations in larval walleye pollock feeding and conditions: a synthesis. Fish Oceanogr 5(Suppl 1):112-123

Utne-Palm AC (1999) The effect of prey mobility, prey contrast, turbidity and spectral composition on the reaction distance of Gobiusculus flavescens to its planktonic prey. J Fish Biol 54:1244-1258

Utne-Palm AC, Stiansen JE (2002) Effect of larval ontogeny, turbulence and light on prey attack rate and swimming activity in herring larvae. Mar Biol 268:147-170

Wood SJR (2000) Modelling and smoothing parameter estimation with multiple quadratic penalties. J R Stat Soc B 62:413-428

Submitted: November 29, 2004; Accepted: April 28, 2005 Proofs received from author(s): October 17, 2005 